\title{
The Effects of Gold and Silver Nanoparticles on Choline Estrase and Monoamino Oxidase Enzymes Activities
}

\author{
Salma Abdul Rudha Abbas \\ Department of Chemistry, College of Science, Al-Mustansiryh University, Iraq \\ E-mail:dr.salma_ar@yahoo.com
}

Received: October 27, 2011

Accepted: November 4, 2011

Published: December 1, 2011

doi:10.5539/ijc.v3n4p61

URL: http://dx.doi.org/10.5539/ijc.v3n4p61

\begin{abstract}
Gold and silver nanoparticles colloids were produced by irradiating a metallic target plates with a thickness of $1 \mathrm{~mm}$ immersed in distilled water with a pulsed laser beam. The size and size distributions of the metals nanoparticles were examined by the transmission electron microscope TEM analysis. The nanoparticles concentrations were also characterized by atomic absorption spectroscopy AAS measurement. The effects of gold and silver nanoparticles were studied on the activities of choline esterase (ChE) and monoamino oxidase (MAO) enzymes in the sera. Gold and silver nanoparticles demonstrated activators effects on the (ChE) and (MAO) activities, and these effects increased with increasing the concentrations of the nanoparticles.
\end{abstract}

Keywords: Neurotransmitters, Activation, Nanocolloids

\section{Introduction}

Laser ablation of bulk target immersed in liquid environment which is simple method, recently has attracted much attention for nanoparticles formation (S.Barcikowski, 2007; S. Besner, 2007; A. Pyatenko, 2009; Y. Fong, 2010). Nanomaterial display unique, superior and indispensable properties and have attracted for their distinct characteristics which are unavailable in conventional macroscopic materials. Their uniqueness arises specifically from higher surface to volume ratio and increased percentage of atoms at the grain boundaries. They represent an important class of materials in the development of novel devices that can be used in various physical, biological, biomedical and pharmaceutical applications (Prashant K, 2007; Nam Jm, 2003; Tkachenko AG, 2003; Hirsch LR, 2003).

\subsection{Neurotransmitter Enzymes}

1-cholinesterase (ChE): is a family of enzymes that catalyze the hydrolysis of neurotransmitter acetyle choline into choline and acetic acid. All choline esterases are proteins with molecular weight ranging from 70.000 to 1000.000 dalton. Choline esterase is more active in human blood cells more than in serum.

There are two types of choline esterase: acetylcholine esterase (EC 3.1.1.7) (AChE or ChE) also known as RBC cholinesterase, erythrocyte cholinesterase or most formally acetyle choline acetyle hydrolase. ChE found in all excitable tissues whether nerve or muscle central and peripheral cholinergic or adrenergic, motor or sensory, in most erythrocyte and in placental tissue, and pseudocholine esterase (EC 3.1.1.8) (BChE) or (BuChE) also known as plasma choline esterase, butyryl cholinesterase or (most formally) acetylcholine aceylhydrolase, found primarily in the liver(Wang R, 2005).

Cholinesterase is such on important enzyme especially in transporting the nerve signals in the nervous system. This enzyme has a vital function in the termination of synaptic transmission by hydrolysis of the neurotransmitter acetylcholine (after completing its function) into choline and acetate.

A very important role in the catalytic activity of choline esterase is played by the amino acids serine, histidine, aspartic acid, and glutamic acid.

There are two active sites in cholinesterase known as the anionic site and the esteratic site. The esteratic site of enzyme combines with the carbonyl group of the ester linkage (acetyle choline) and this site is responsible for the hydrolysis of the ester bond (Ballantyne B, 1992; Huang YJ, 2007). 
2-Monoamino oxidase (MAO) (EC 1.4.3.4): is an outer mitochondrial membrane containing enzyme, is found in nearly all tissues. Two major isoforms have been described, the MAO-A and the MAO-B made up of different polypeptides (C.W.Abell, 2001; C.Binda, 2002). The MAO is responsible for the major neurotransmitter degrading in the central nervous system (CNS) and peripheral tissues (Youdim M, 2005). MAO-A preferentially catalyzes the oxidative deamination of serotonin, adrenaline. MAO-B mainly catalyzes the oxidative deamination of phenyl ethyl amine and benzyl amine. Both isoforms act either on dopamine invitro or on tyramine. In man kind, dopamine is preferentially deaminated by MAO-B, because of their role in the metabolism of mono amine neurotransmitters, the MAO-A and MAO-B are thought to be involved in psychiatric and neurological disorders such as depression and parknson's disease, respectively (Moussa B H, 2006; P.H.Seeburg, 2003).

\section{Materials and methods}

\subsection{Nanoparticles Preparation}

Gold and silver nanoparticles colloids were produced by irradiating a metallic target plates with a thickness of $1 \mathrm{~mm}$ immersed in distilled water with a pulsed laser beam. The ablation was performed with the $(1064 \mathrm{~nm})$ of a Nd: YAG laser (HUAFEI) operating at $10 \mathrm{~Hz}$ repetition rate, with a pulse width of $10 \mathrm{~ns}$. The beam was focused on the surface of the target through a lens with $11 \mathrm{~cm}$ of focal length. The spot size was about $1.5 \mathrm{~mm}$ in diameter. The size and size distributions of the metals nanoparticles were examined by the transmission electron microscope TEM analysis, using a CM10 pw6020, Philips-Germany.

UV-vis absorption spectroscopy measurements were carried out on a double beam, CECIL C. 7200 (France) spectrophotometer. The nanoparticle concentrations were also characterized by Atomic absorption spectroscopy AAS measurement (model GBS 933, Australia), was carried out for the prepared samples.

\subsection{Acetylcholinesterase activity}

Acetylcholinesterase activity was assayed by Ellman method (Ellman G.L, 1961; Balgiz W.kamas, 2001; Mansour M, 2001). The principle of the method is the measurement of the rate of production of thiocholine as acetyl thiocholine is hydrolyzed. This was accomplished by the continuous reaction of the thiol with 5.5-dithiobis-2-nitrobenzoic acid (DTNB) to produce the yellow color of 5-thio-2-nitrobenzoic acid. The rate of color production is measured at $430 \mathrm{~nm}$. The assay procedure is described as follows:

$1-(50 \mu \mathrm{L})$ of DTNB solution $(0.001 \mathrm{M})$ is added to $(2.25 \mathrm{~mL})$ of sodium phosphate buffer solution $(\mathrm{pH}=7.3,0.2$ $\mathrm{M})$, then $(10 \mu \mathrm{L})$ of serum is added, mixed well and $(2 \mathrm{~mL})$ of the mixture is transferred to a measuring cell $(3$ $\mathrm{mm})$, then $(34 \mu \mathrm{L})$ of acetylthiocholine iodide (ASChI $0.06 \mathrm{M})$ is added, the change in absorbency is measured before and after adding the substrate at $(430 \mathrm{~mm})$ for $(3 \mathrm{~min})$. The enzyme activity is calculated as the concentration in $\mu$ mole of the substrate hydrolyzed to each $(\mathrm{mL})$ of sample in (3 minute) and expressed as $(\mu \mathrm{mole} / 3 \mathrm{~min} / \mathrm{mL})$.

2-A stock colloid $(15 \mathrm{ppm})$ concentration of gold nanoparticles and $(20 \mathrm{ppm})$ concentration of silver nanoparticles and then the following concentrations $(1,3,6,9,12) \mathrm{ppm}$ of gold nanoparticles and $(1,3,6,9,12$, 15) ppm of silver nanoparticles are prepared. The different concentrations of the nanoparticles are prepared by diluting with deionized water using the stock colloid. ChE activity is measured in human serum by using the same method with replace $2.25 \mathrm{~mL}$ of $\mathrm{ChE}$ buffer solution with $2.0 \mathrm{~mL} \mathrm{ChE} \mathrm{buffer}+0.25 \mathrm{~mL}$ of different concentration of nanoparticles.

\subsection{Mono amino oxidase activity}

Mono amino oxidase activity was assayed by Mcewen and Cohen method (M.Charles, 1963). The principle of the method is the measurement of the benzaldehyde which obtained reaction which is absorbed at wave length $242 \mathrm{~nm}$ after extraction by cyclohexane.

A-The assay procedure is described in this table:

\begin{tabular}{|c|c|c|}
\hline Solution & Test & Control \\
\hline Serum & $600 \mu \mathrm{L}$ & $600 \mu \mathrm{L}$ \\
\hline MAO buffer & $750 \mu \mathrm{L}$ & $750 \mu \mathrm{L}$ \\
\hline Benzalamine & $150 \mu \mathrm{L}$ & $\ldots \ldots \ldots$ \\
\hline
\end{tabular}


Water bath shaking for $3 \mathrm{hrs}$. at $37^{\circ} \mathrm{C}$.

\begin{tabular}{|c|c|c|}
\hline Benzalamine & $\ldots \ldots$. & $150 \mu \mathrm{L}$ \\
\hline Perchloric acid & $150 \mu \mathrm{L}$ & $150 \mu \mathrm{L}$ \\
\hline cyclohexane & $1.5 \mu \mathrm{L}$ & $1.5 \mu \mathrm{L}$ \\
\hline
\end{tabular}

Mixed, and centrifugation for $10 \mathrm{~min}$. Then measure absorbance of supernatant at $242 \mathrm{~nm}$. Enzyme activity measured through aldehyde formed in $3 \mathrm{hrs}$.

MAO activity is measured in human serum by using the same method with replace $750 \mu \mathrm{L}$ of MAO buffer solution with $500 \mu \mathrm{L}$ MAO buffer $+250 \mu \mathrm{L}$ of different concentration of nanoparticles.

The activation percentages of $\mathrm{ChE}$ and MAO were calculated by comparing the activities with and without the nanoparticles under the same conditions, according to the equation:

$\%$ activation $=$ Activity in the presence of nanoparticles / Activity in the absence of nanoparticles x $100-100$

A constant concentration of $\mathrm{Au}$ and $\mathrm{Ag}$ nanoparticles (12 ppm) was used with different substrates of ChE and MAO concentrations $(0.02,0.04,0.06,0.08,0.09) \mathrm{M}$, to calculate the Ki, apparent Vmax (Vmapp), apparent Km (Kmapp). These different concentrations were prepared from the stock solution of (0.1 M) MAO and ChE substrates. The enzymes activities were determined with and without the nanoparticles, by using the Lineweaver-Burk equation and plotting 1/v against 1/[s] (M.P.Kutyreva, 2001).

\section{Results and discussion}

This research addresses on preparation of pure noble metals of Au and Ag nanoparticles colloids, which have significant biological and chemical effects (Prashant K, 2007; Nam Jm, 2003; Tkachenko AG, 2003; Hirsch LR, 2003; Bhupendra, 2010; Mulvaney,P., 1996; J.L.Elechiguerra, 2005; M.Raffi, 2008), and investigation of the effects on activities of (ChE and MAO) enzymes.

Fig. 1 (A and B), shows the extinction spectra of colloidal solutions of Ag and Au samples, respectively. The Nd-YAG laser of $1064 \mathrm{~nm}$ was utilized as an ablation source. The pulse energy at the target surface was varied in the range $(300-600 \mathrm{~mJ})$ and the beam was focused to have a diameter near the outer edges of the target of 1.27 and $0.85 \mathrm{~mm}$ for $\mathrm{Ag}$ and $\mathrm{Au}$, respectively. The metal plate was fixed in a glass vessel filled with $1 \mathrm{ml}$ DDDW thus the smokelike colloids above the metal plate was observed. The plate was located at 8 and $7 \mathrm{~mm}$ from the liquid surface for $\mathrm{Ag}$ and $\mathrm{Au}$, respectively. Laser ablation listed for 15 pulses and the solution gradually turned to colored with the increase of the number of laser pulses. Fig. 1 (A) shows the Absorbance peaks that occurred at around $400 \mathrm{~nm}$ is the characteristic SPE signature of Ag nanoparticles (X.P. Zhum, 2006). Fig 1-B shows broad band with the Absorbance peak around $526 \mathrm{~nm}$ with the peak position remaining practically constant, that indicates the production of gold nanoparticles (N.V. Tarasenko, 2006). We observed a faint pink coloration of the solution after several pulses of the experiment. In the absorption spectra of the solutions, the surface plasmon related peak could be clearly distinguished. This peak was around $520-530 \mathrm{~nm}$, which was consistent with the presence of small $3-30 \mathrm{~nm}$ particles in the colloid (F.Mafune, 2002), which also confirmed by TEM.

Figure 2 (A and B) shows the TEM images and corresponding size distributions of silver and gold nanoparticles, produced by laser ablation of silver plate immersed in pure water. The nanoparticles thus produced were calculated to have the average diameters of $14 \mathrm{~nm}$. It is observed that the average diameter and size distribution was increased with the increase of the laser energy. The origin of the surface morphology of the irregularly shaped particles sizes and the size distribution broadens can be explained by absorption by defects and thermally induced pressure pulses which cause cracking (O.R. Musaev, 2010).

The biochemical tests revealed that gold and silver nanoparticles colloids, moderate to good activation effects on the (ChE and MAO) enzymes activities, the normal values of the (ChE and MAO) enzymes activities without nanoparticles colloids are $(5.26,22.4) \mu \mathrm{mole} / 3 \mathrm{~min} / \mathrm{mL}$ respectively.

The relationships between nanoparticles colloids concentrations versus and the activities of enzymes are shown in figures (3 and 4), from these results it is observed that any increase in nanoparticles colloids concentrations causes increasing activation of enzymes.

Percentages of activation of enzymes are shown in figures $(5,6)$. Silver nanoparticles colloid, in 15 ppm concentration, exhibited higher percentage of activation of ChE (90.49\%) than gold nanoparticles colloid 
(34.6\%). Percentage of activation of MAO enzyme that revealed in gold nanoparticles colloid (31.43\%) higher than silver nanoparticles colloid ( $28.73 \%)$, in $15 \mathrm{ppm}$ concentration.

Kinetic parameters (Kmapp, Vmapp, and Ka) with (12 ppm) concentration of gold and silver nanoparticles colloids were also determined at different concentrations of substrate and under the same conditions by using lineweaver - Burk equation (Satyanarayna, 2003) and plotted as shown in figures (7 and 8) and table (1).

Table (1) and figure (7) showed that the Vmax and $\mathrm{Km}$ on ChE enzyme activity with (12) ppm of Au and Ag nanoparticles and without it, $\mathrm{Vmax}$ and $\mathrm{Km}$ without $\mathrm{Au}$ or $\mathrm{Ag}$ nanoparticles of $\mathrm{ChE}$ enzyme were 10 $\mu \mathrm{mole} / 3 \mathrm{~min} / \mathrm{mL}, 0.06 \mathrm{M}$ respectively.

A liquate (12 ppm) of Au nanoparticles was activation of ChE enzyme and changed the Vmax of the enzyme to Vmapp (14.29) $\mu \mathrm{mole} / 3 \mathrm{~min} / \mathrm{mL}$. By using Lineweaver-Burk equation was calculated the Ka value of $\mathrm{ChE}$ enzyme for Au nanoparticles which was studied in different concentration of substance, the Ka was $40 \mathrm{M}$.

Table (1) and figure (7) showed that the Vmax and $\mathrm{Km}$ on ChE enzyme activity with (12 ppm) of $\mathrm{Ag}$ nanoparticles, which was activation of $\mathrm{ChE}$ enzyme and changed the $\mathrm{Km}$ of the enzyme to Kmapp (0.025) M. By using Lineweaver-Burk equation was calculated the Ka value of $\mathrm{ChE}$ enzyme for Ag nanoparticles which was studied in different concentration of substance, the Ka was $20.87 \mathrm{M}$.

Table (1) and figure (8) showed that the Vmax and $\mathrm{Km}$ on MAO enzyme activity with (12) ppm of Au and Ag nanoparticles and without it, $\mathrm{Vmax}$ and $\mathrm{Km}$ without $\mathrm{Au}$ or $\mathrm{Ag}$ nanoparticles of MAO enzyme were 28.57 $\mu \mathrm{mole} / 3 \mathrm{~min} / \mathrm{mL}, 0.0025 \mathrm{M}$ respectively.

A liquate (12 ppm) of Au nanoparticles was activation of MAO enzyme and changed the Vmax of the enzyme to Vmapp $31.25 \mu \mathrm{mole} / 3 \mathrm{~min} / \mathrm{mL}$. Ka value of MAO enzyme for Au nanoparticles which was studied in different concentration of substance, the Ka was $139.5 \mathrm{M}$.

Table (1) and figure (8) showed that the Vmax and $\mathrm{Km}$ on MAO enzyme activity with (12 ppm) of Ag nanoparticles, which was activation of MAO enzyme and changed the Vmax of the enzyme to Vmapp 33.33 $\mu \mathrm{mole} / 3 \mathrm{~min} / \mathrm{mL}$. Ka value of MAO enzyme for Ag nanoparticles was $84.00 \mathrm{M}$.

The present work is the first study that demonstrates the effects of gold and silver nanoparticles colloids on the activities of $\mathrm{ChE}$ and MAO enzymes. Some recent researches demonstrated that gold nanoparticles colloids can be used in diagnosis and treatment of some kinds of cancer (Prashant K, 2007; Nam Jm, 2003; Tkachenko AG, 2003; Hirsch LR, 2003; Mulvaney, P., 1996; Brigger I, 2002). Other researches proved that silver nanoparticles colloids are anti-bacterial (Bhupendra, 2010; Mulvaney P., 1996; J.L.Elechiguerra, 2005; M.Raffi, 2008). Therefore, it was useful to know what is the effects of gold and silver nanoparticles colloids on activities of the different enzymes when enter to the human body, then it would be known what the side effects of gold and silver nanoparticles colloids on the human body is. ChE and MAO are important enzymes which are found in the human body because they are responsible for the major neurotransmitter degrading in the central nervous system (CNS) and peripheral tissues. Activation or inhibition of $\mathrm{ChE}$ and MAO by chemicals effects the transporting of nerve signals in the nervous system, this research proved that gold and silver nanoparticles colloids activated $\mathrm{ChE}$ and MAO enzymes. Therefore, transporting of the nerve signals in the nervous system were decreased and then muscle relaxations increase.

\section{References}

A. Pyatenko, M. Yamaguchi, \& M. Suzuki. (2009). Mechanisms of Size Reduction of Colloidal Silver and Gold Nanoparticles Irradiated by, Nd: YAG Laser. J. Phys. Chem., 113, 9078-9085.

Balgiz W.kamas. (2001). M.sc. thesis, college of science, Al-Mustansirya university.

Ballantyne B., \& Marrs T.C. (1992). clinical and experimental toxicology of organophosphatase and carbamates Butteworth-Heinemann. Oxford.

Bhupendra Chudasama. Anjana K.Vala., Nidhi Andhariya.R.V.Mehta., \& R.V.Updhyay. (2010). Highly bacterial resistant silver nanoparticles:synthesis and antibacterial activities, J.Nanopat Res., 10, January.

Brigger, I., C. Dubernet, \& P. Couvreur. (2002). Nanoparticles in cancer therapy and diagnosis Adv. Drug Delivery. Rev.54:631-651C.W.Abell, \& S. W. Kwan. (2001). molecular characterization of monoamine oxidases A and B, Prog.Nucleic acid Res.Mol.Biol., 65, 129-156.

C. Binda, P. N. Vision, F. Hubalek, D. E. Edmondson, \& A. Matteri. (2002). Structure of human monoamine oxidase B, a drug target for the treatment of neurological disorders, Nat. struct. Biol., 9, 1-5. http://dx.doi.org/10.1038/nsb0102-1 
Ellman G.L., Courtney K.P., Andres V., \& Feather Stone R.M. (1961). Biochem. Pharmacol, Vol.7, pp. 88-91. http://dx.doi.org/10.1016/0006-2952(61)90145-9

F. Mafune, J. Kohno, Y. Takeda, \& T. Kondow. (2002). Full Physical Preparation of Size-Selected Gold Nanoparticles in Solution: Laser Ablation and Laser-Induced Size Control. American Chemical Society., 106, 7575-7578.

Hirsch LR, Stafford RJ, Bankson JA, Sershen SR, Rivera B, Price RE, Hazle JD, Halas NJ, \& West JL. (2003). Nanoshell-mediated near-infrared thermal therapy of tumors under magnetic resonance guidance. PNAS, 100, 13549-13554. http://dx.doi.org/10.1073/pnas.2232479100

Huang YJ, Huang Y, Baldassarre H, Wang B, Lazaris A, Leduc M, Bilodeau AS, Bellemare A, Côté M, Herskovits P, Touati M, Turcotte C, Valeanu L, Lemée N, Wilgus H, Bégin I, Bhatia B, Rao K, Neveu N, Brochu E, Pierson J, Hockley DK, Cerasoli DM, Lenz DE, Karatzas CN, \& Langermann S. (August 2007). Recombinant human butyrylcholinesterase from milk of transgenic animals to protect against organophosphate poisoning. Proc. Natl. Acad. Sci., U.S.A., 104(34), 13603-8. http://dx.doi.org/10.1073/pnas.0702756104

J.L. Elechiguerra, J.L. Burt, \& J.R. Morones. (2005). Interaction of silver nanoparticles with HIV-I. Journal of Nanobiotechnology, 6(3), 1-10.

Mansour M. Mahmmed. (2000). M.Sc. thesis, college of science, Al- Mustansiriya University.

M. Charles, J.R. Mcewen, \& J.D. cohen. (1963). J.Lab and Clin. Med, 62, 766.

Moussa B H Youdim1, \& Y S Bakhle. (2006). Monoamine oxidase: isoforms and inhibitors in Parkinson's disease and depressive illness. Br J Pharmacol. January, 147(S1), S287-S296.

M.P. Kutyreva, E.P. Medyntseva, et al. (2001). Kinetic parameters of choline estrase catalyzed hydrolysis in the presence of the antigen-antibody immune complex. Russian Journal of general chemistry, 71(1), 329-338.

M. Raffi. F. Hussain, T. M. Bhatti, J. I. Akter, A. Hameed, \& M. M. Hasan. (2008). Antibacterial Characterization of Silver Nanoparticles against E.Coli ATCC-15224. J.Mater. Sci. Technol., 24(2), 192-196.

Mulvaney P. (1996). Surface plasmon spectroscopy of nanosized metal particles. Langmuir, 12, 788-800. http://dx.doi.org/10.1021/la9502711

Nam Jm, Thaxton CS, \& Mirkin CA. (2003). Nanoparticle-based bio-bar codes for the ultrasensitive detection of proteins. Science, 301, 184-16.

N.V. Tarasenko, A.V. Butsen, E.A. Nevar, \& N.A. Savastenko. (2006). Synthesis of nanosized particles during laser ablation of gold in water. Applied Surface Science, 252, 4439-4444. http://dx.doi.org/10.1016/j.apsusc.2005.07.150

O.R. Musaev, A.E. Midgley, J.M. Wrobel, \& M.B. Kruger. (2010) Laser ablation of alumina in water. Chemical Physics Letters, 487, 81-83. http://dx.doi.org/10.1016/j.cplett.2010.01.011

P.H.Seeburg, R. Silvestri, G.La Regina, G. De Martion, \& MArtico. (2003). Simple,potent,and selective pyrrole inhibitors of monoamine oxidase types A and B. J.med chem., 46, 917-920. http://dx.doi.org/10.1021/jm0256124

Prashant K. Jain, Ivan H. El-Sayed, \& Mostafa A. El-Sayad. (2007). Au Nanoparticles target. Cancer, Nanotoday, 2(1), 18-29. http://dx.doi.org/10.1016/S1748-0132(07)70016-6

Satyanarayna U. (2003). Biochemistry 2nd ed, Books and Allied (P) LTD, India, pp 91-94.

S. Barcikowski, A. Menendez-Manjon, \& B. Chichkov. (2007). Generation of nanoparticle colloids by picosecond and femtosecond laser ablations in liquid flow. Applied Physics Letters, 91, 083113. http://dx.doi.org/10.1063/1.2773937

S. Besner, A.V. Kabashin, \& M. Meunier. (2007). Two-step femtosecond laser ablation-based method for the synthesis of stable and ultra-pure gold nanoparticles in water. Appl. Phys., A88, 269-272. http://dx.doi.org/10.1007/s00339-007-4001-1

Tkachenko AG, Xie H, Coleman D, Glomm W, Ryan J, Anderson MF, Franzen S, \& Feldheim DL. (2003). Multifunctional Gold Nanoparticle- Peptide Complexes for Nuclear Targeting. J Am Chem Soc., 125, 4700-4701. http://dx.doi.org/10.1021/ja0296935

Y. Fong, J. R. Gascooke, B. R. Visser, G.F. Metha, \& M. A. Buntine. (2010). Laser-Based Formation and Properties of Gold Nanoparticles in Aqueous Solution: Formation Kinetics and Surfactant-Modified Particle Size Distributions. J. Phys. Chem. C, 114, 15931-15940. http://dx.doi.org/10.1021/jp9118315 
Youdim M.B., \& Buccafusco J.J. (2005). Multi-functional drugs for various CNS targets in the treatment of neurodegenerative disorders. Trends Pharmacol. Sci., 26, 27-35. http://dx.doi.org/10.1016/j.tips.2004.11.007

Wang R, \& Tang XC. (2005). Neuroprotective Effects of Huperzine A. Neurosignals, 14(1-2), 71-82. http://dx.doi.org/10.1159/000085387

X.P. Zhu, T. Suzuki, T. Nakayama, H. Suematsu, W. Jiang, \& K. Niihara. (2006). Underwater laser ablation approach to fabricating monodisperse metallic nanoparticles. Chemical Physics Letters, 427, 127-131. http://dx.doi.org/10.1016/j.cplett.2006.05.119

Table 1. The kinetic properties of $\mathrm{ChE}$ and $\mathrm{MAO}$ with $\mathrm{Au}$ and $\mathrm{Ag}$ nanoparticles

\begin{tabular}{|c|c|c|c|c|c|c|}
\hline \multirow{2}{*}{ Nanoparticle } & Enzyme & $\begin{array}{c}\text { Vmax } \\
\mu \mathrm{mole} / 3 \mathrm{~min} / \mathrm{mL}\end{array}$ & $\mathbf{K m ~ M}$ & $\mathbf{K}_{\text {map }} \mathbf{M}$ & $\begin{array}{c}\text { V map } \\
\mu \mathrm{mole} / 3 \mathrm{~min} / \mathrm{mL}\end{array}$ & $\mathbf{K a} \mathbf{M}$ \\
\hline \multirow{2}{*}{ Au } & $\mathbf{C h E}$ & 10 & 0.06 & 0.06 & 14.29 & 40 \\
\cline { 2 - 7 } & $\mathbf{M A O}$ & 28.57 & 0.0025 & 0.0025 & 31.25 & 139.5 \\
\hline \multirow{2}{*}{ Ag } & $\mathbf{C h E}$ & 10 & 0.06 & 0.025 & 10 & 20.87 \\
\cline { 2 - 7 } & $\mathbf{M A O}$ & 28.57 & 0.0025 & 0.0025 & 33.33 & 84.00 \\
\hline
\end{tabular}

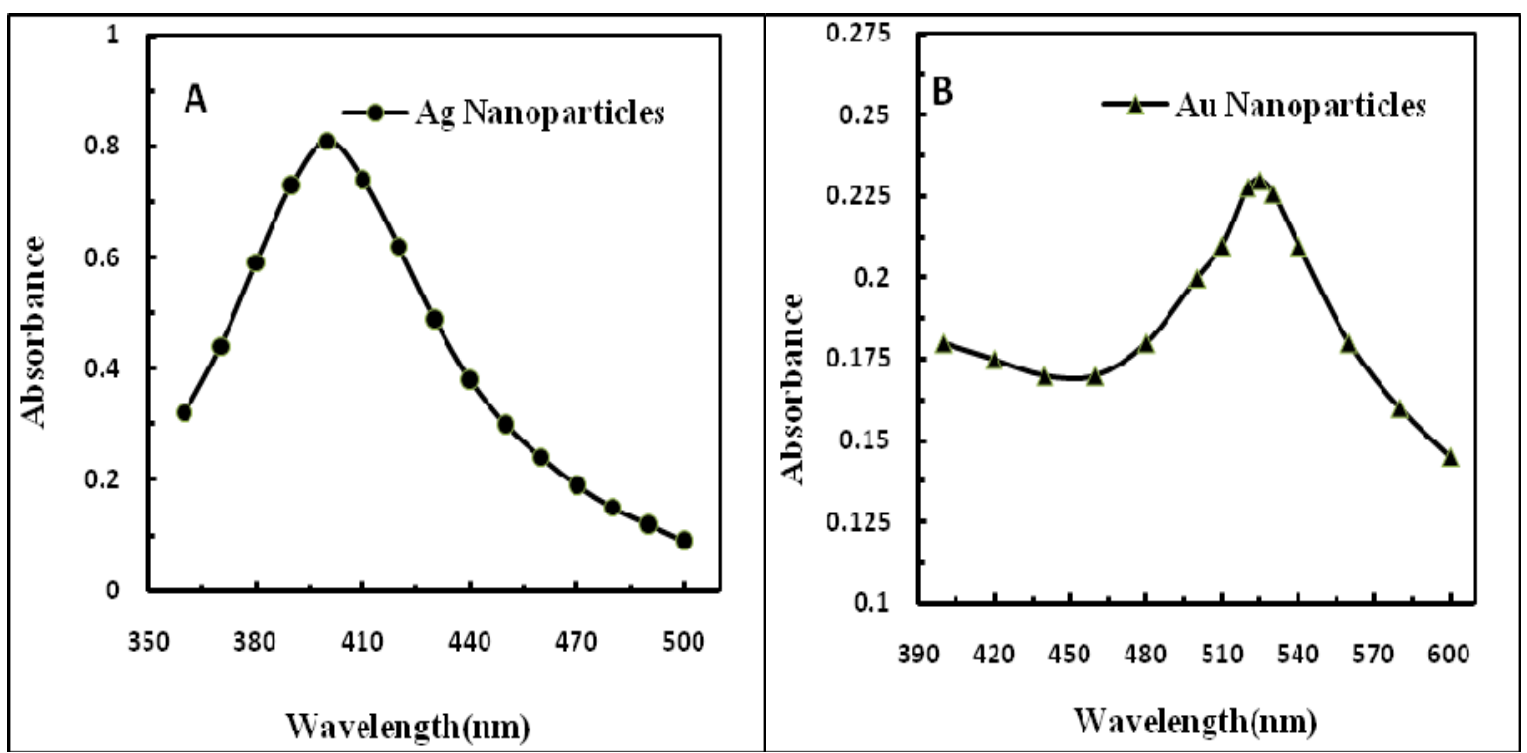

Figure 1. Absorbance spectra of silver nanoparticles (A), and gold nanoparticles (B), obtained by laser ablation of metal plates immersed in DDDW with laser energy of $600 \mathrm{~mJ}$, laser shots of 15 pulses and wave length is $1064 \mathrm{~nm}$ of Nd-YAG 


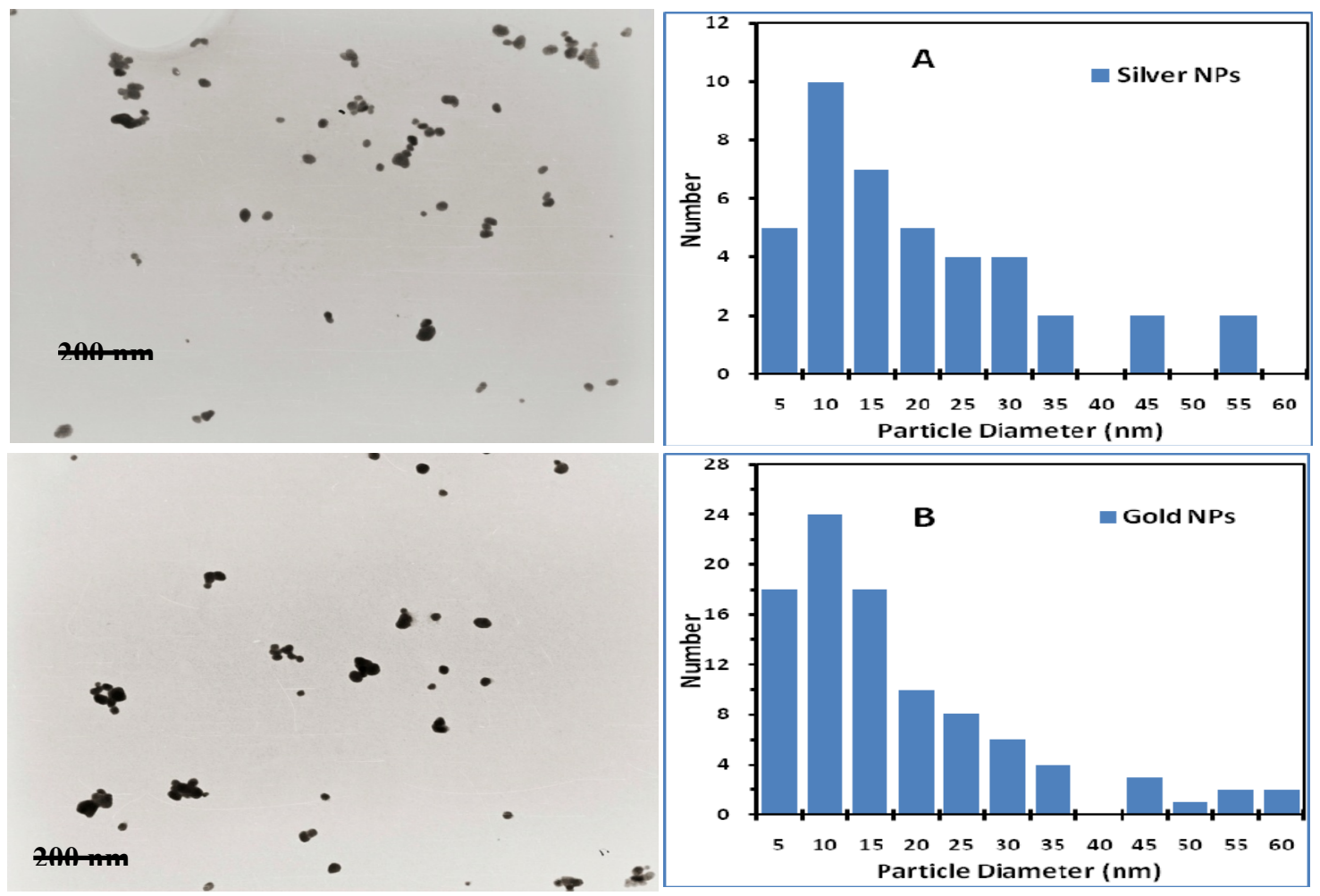

Figure 2. TEM images and size distributions of silver (A), and gold nanoparticles (B), produced by laser ablation of metal plats immersed in pure water, $(\lambda=1064 \mathrm{~nm}$ and laser shots of 15 pulses $)$

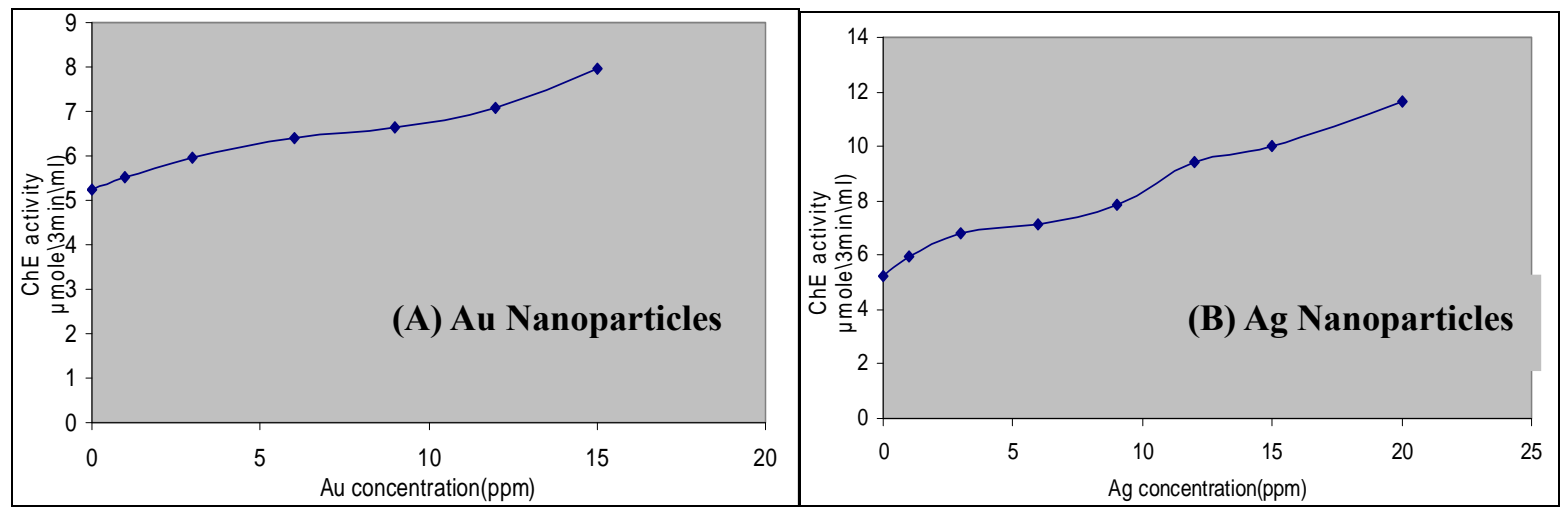

Figure 3. ChE enzyme activity as a function of concentration of (A) Au nanoparticales (B) Ag nanoparticles
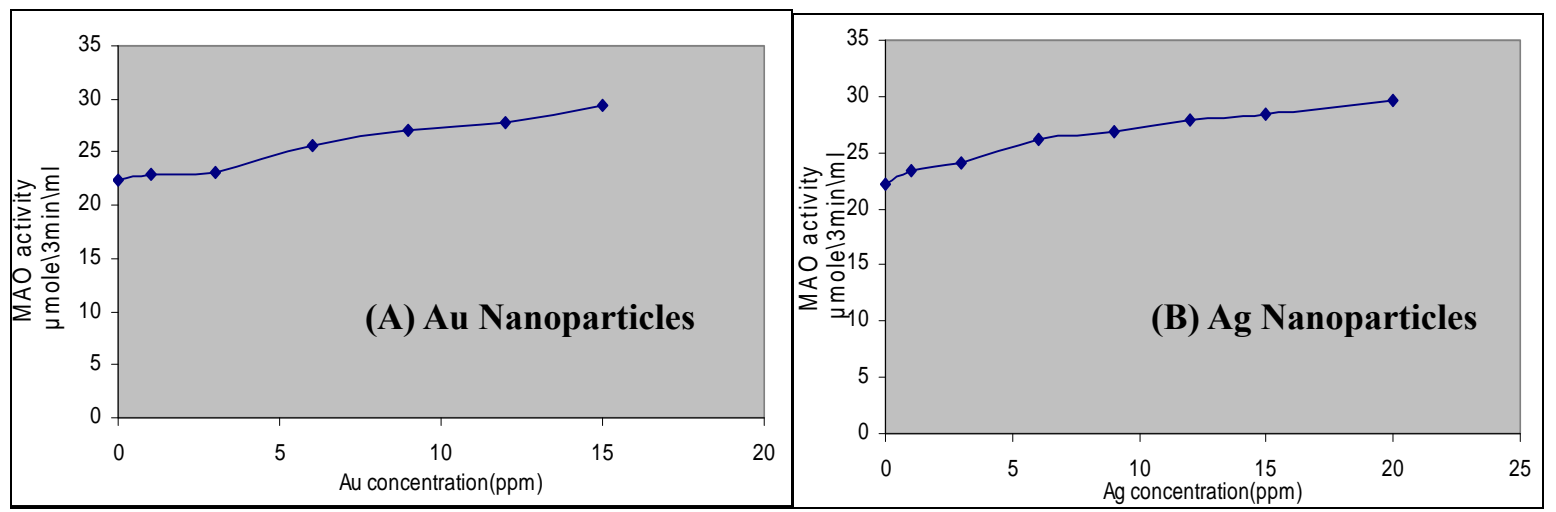

Figure 4. MAO enzyme activity as a function of concentration of (A) Au nanoparticales (B) Ag nanoparticles 


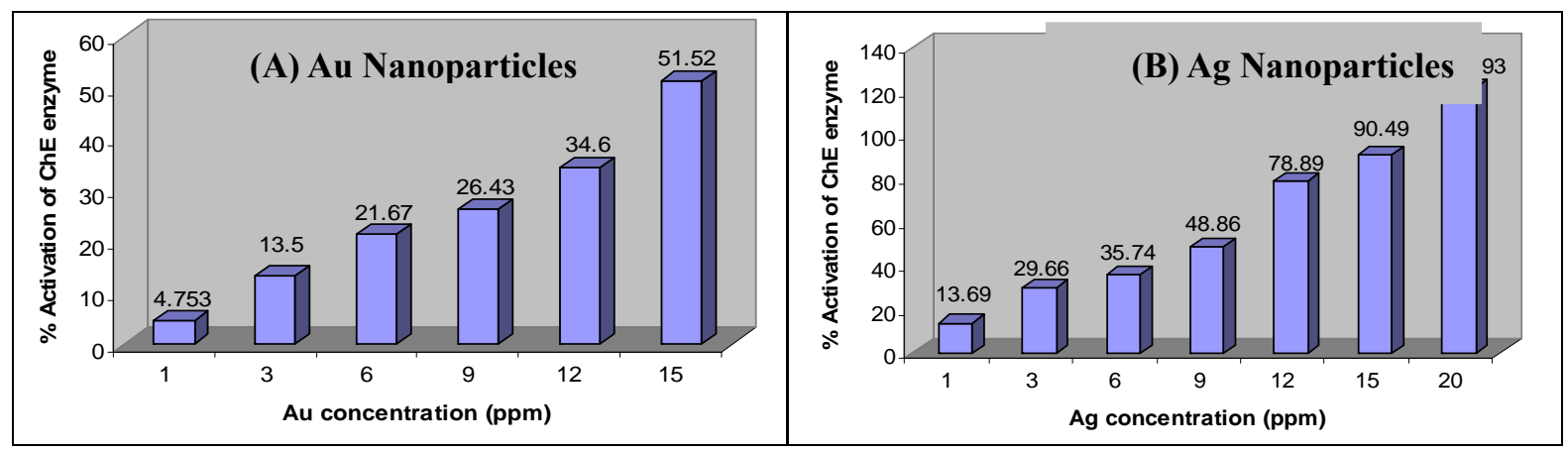

Figure 5. \% Activation of ChE enzyme and (A)Au nanoparticles concentrations (B) Ag nanoparticles concentrations

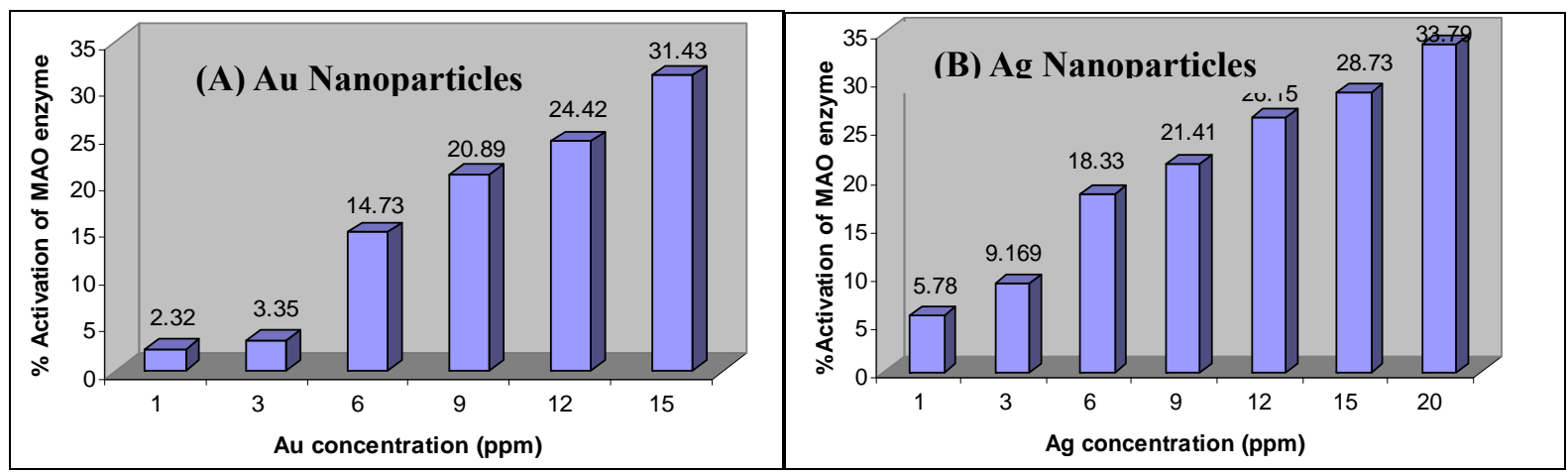

Figure 6. \% Activation of MAO enzyme and (A)Au nanoparticles concentrations (B) Ag nanoparticles concentration
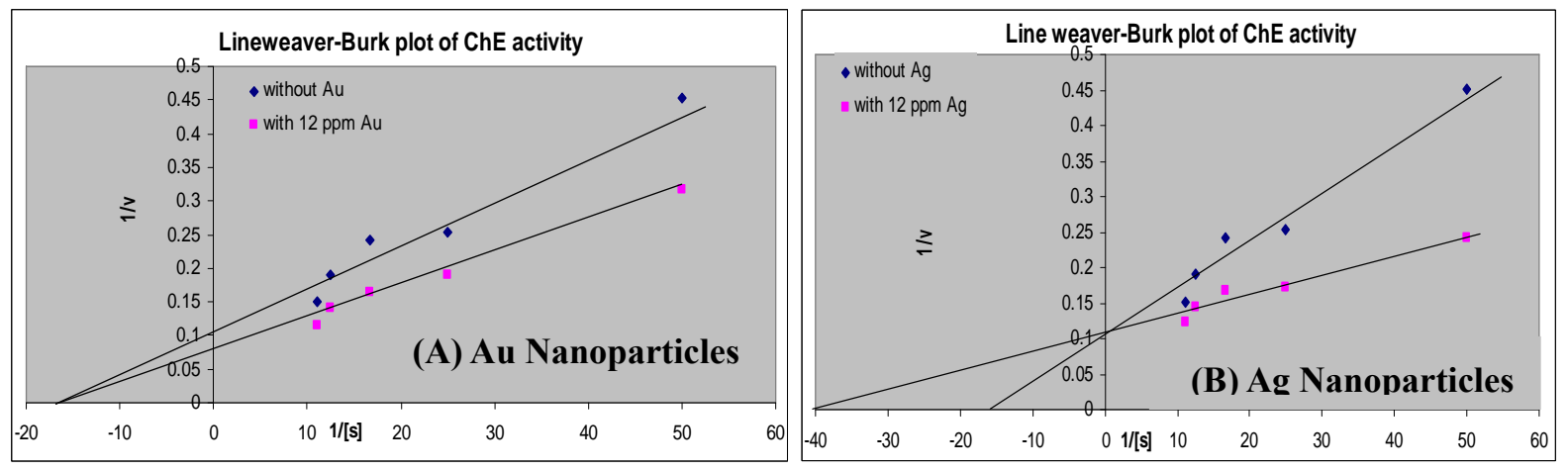

Figure 7. Lineweaver-Burk plots for (A) Au and (B) Ag nanoparticales effects on $\mathrm{ChE}$
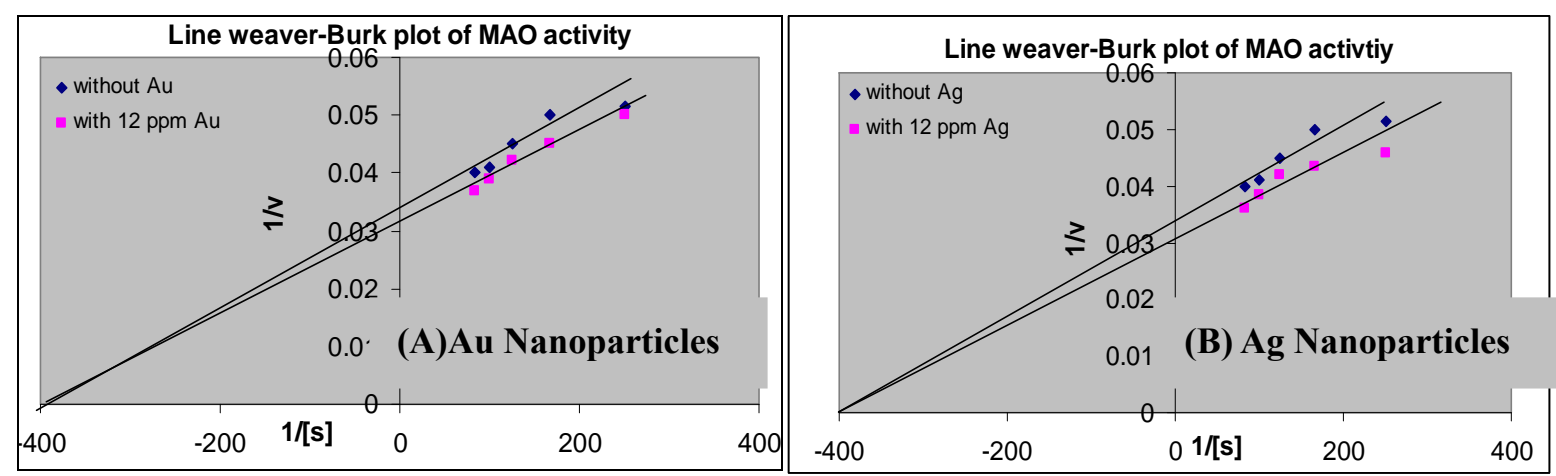

Figure 8. Lineweaver-Burk plots for (A) Au and (B) Ag nanoparticales effects on MAO 